DOI: 10.1515/pof-2016-0015

VOLUME 8, ISSUE 3, 2016

ISSN: $2036-5438$

\title{
Constitutional Politics in East Germany and the Grand Coalition State
}

by

Werner Reutter*

Perspectives on Federalism, Vol. 8, issue 3, 2016 


\begin{abstract}
Constitutional politics seemingly corroborate the assumption that Germany is a Grand Coalition state. In this perspective German cooperative federalism and the supermajority required for any amendment to the constitution privilege bargaining and intertwined policy-making as modes of conflict resolution and thus support grand coalitions. In this paper I will explore whether this theory can explain constitutional politics in the German Länder. Firstly, I examine how far sub-national constitutional politics match the functioning of cooperative federalism that is a defining feature of the Grand Coalition state. Secondly, I examine sub-national constitutional politics in the five new Länder and bring the role parties played in this policy field to the fore. Overall, I conclude that cooperative federalism did not impact on constitutional politics in East Germany and that the features of consensus democracy are only partly able to explain law-making in this sector.
\end{abstract}

Key-words

Land constitutions, German federalism, Grand Coalition state, consensus democracy, majoritarian democracy 
Apparently, constitutional politics corroborate the hypothesis that Germany is a Grand Coalition state or a "state which embodies high "dispersal of power"” and thus privileges bargaining and compromise as modes of conflict resolution (Schmidt 2008: 79; cf. also Katzenstein 1987; Schmidt 1987). In this perspective decisions that require a two-thirds majority cannot but strengthen the consensus democracy component and the Grand Coalition component in Germany's polity' (Schmidt 2008: 72; cf. also: Reutter 2010; Lijphart 1999). Such decisions leave governments only few options: If they want to change the constitution, they have to cooperate with parties whose greatest ambition is to unsettle that very government. As far as constitutional politics is concerned Germany seems nothing but a consensus democracy or a Grand Coalition state ${ }^{\mathrm{I}}$ 'that is, a government Goliath tied down by powerful formal or informal checks and balances and co-governing institutions' (Schmidt 2008: 79).

It bears noting, though, that Manfred G. Schmidt who coined the term Grand Coalition state only referred to the national level. At the national level we find divided governments and co-governing institutions establishing the structural set-up for consensual policy-making in Germany. However, what about the Länder? Obviously, they can hardly be tied down by the same 'formal or informal checks and balances' as the national Goliath. In the Länder there are neither second chambers like the federal council nor constitutional courts enjoying the same or similar competencies as the federal constitutional court at the national level (Reutter 2017). What does this mean for constitutional politics in the Länder? In this article, I will try to find answers to these questions and examine how far constitutional politics in the East German Länder confirm the assumption that Germany is a Grand Coalition state and whether consensus democracy has effectively operated at this level and in this policy-field, as well. In methodological terms constitutional politics of the five new Länder seem to be ideal to tackle the questions at hand and to examine whether policy-making in this sector shares features complying with functional principles of German consensus democracy. East German Länder and their constitutions shared similar initial conditions as far as this policy sector were concerned. After joining the FRG they all had to establish a new system and adopt a new constitution (Lorenz 2013). Hence, my study tries to shed some light on the assumption that the functioning principles of the 
German Grand coalition state not only shapes policy-making at the national level but also works in a sector that is supposed to notably represent the autonomy of the Länder.

In order to address issues linked to the theory of the Grand Coalition state I will analyse two crucial elements of German consensus democracy as far as these pertain to sub-national constitutional politics. I will firstly explore how the federal system or the vertical division of tasks between the national and the sub-national level impacts on this policy sector. As far as the Grand-Coalition-state hypothesis is concerned this is a crucial dimension because policy-making has been shaped by the functional principles of cooperative federalism in many sectors (Schmidt 2008: 79 ff.). I will explore how far these principles also apply with regard to sub-national constitutional politics. In a second step, I examine if and in what respect constitutional politics in eastern Germany fit with the aforementioned logic of consensus democracy. As any amendment to an East German constitution requires a two-thirds majority in parliament it might plausibly be assumed that they also strengthen the Grand Coalition component at the Länder level.

German political scientists have only recently begun to examine sub-national constitutional politics (Reutter 2008; Lorenz/Reutter 2012; Flick 2008a; Hölscheidt 1995; Reutter/Lorenz 2015). Yet, none of these studies explores constitutional politics in the five new Länder in an encompassing way and in the perspective laid out above (Jesse et al. 2014: 51-68; Gunlicks 2003: 141-62; Lorenz 2011). In addition, the prevailing research mainly focuses on the question of whether and how far constitutional rigidity affected the number of amendments to German Land constitutions (Flick 2008a). However, in order to capture constitutional politics I do not only have to include adopted amendments into the analysis but all drafted bills that aimed at changing East German constitutions. ${ }^{\text {II }}$

\section{Cooperative federalism, sub-national constitutional politics and the Grand Coalition state}

German federalism splits sovereignty between the federation and the Länder in a specific fashion. Most importantly, the division of competencies between the federation and the Länder makes cooperation and intertwined policy-making obligatory. The separation of tasks therefore causes a 'network-like system of interlocking politics' in which each participant enjoys 'veto power of considerable strength' (Schmidt 2008: 80 and 81). 
These structures seemingly privilege co-operation among Land executives and bargaining as a major mode of conflict resolution as well as privilege unitarian and homogeneous policies. In a nutshell this is the textbook interpretation of German federalism and a core element of the Grand Coalition state (Kropp 2010; Laufer/Münch 2010).

Seemingly, sub-national constitutional politics fits perfectly with this understanding for two reasons: On the one hand, the people in the Länder are not sovereign and sub-national constitutions are not merely an expression of decisions made by the demoi of the Länder. They are part of a federal state and thus have to comply with provisions laid down in the federal constitution. In order to make sure that the sub-national constitutions are in line with the federal order the Basic Law circumscribes the Länder's competencies in this area (Lorenz/Reutter 2012; Gunlicks 2012). Art. 28 par. 1 of the German Basic Law (BL) requires Land constitutions to conform to the principles of a republican, democratic and social state governed by the rule of law within the meaning of the Basic Law. Due to this 'homogeneity clause' many scholars see Land constitutions 'overshadowed by the Basic Law' (Möstl 2005). In this dominating perspective the BL allots constitutional space to the Länder, enclose Land constitutions and overrules regulations contradicting the BL (like the existing death penalty in the constitution of Hesse). On the other hand, ideas seem to travel easily between the German Länder. C. Pestalozza (2014a) for example claims that there is a tendency towards standardised sub-national constitutions in Germany sometimes based on consultation, sometimes on imitation. Many scholars see sub-national constitutions, therefore, not only shaped by the national level but also by processes of adaptation and homogenisation which could eventually even jeopardise a crucial precondition of federalism: diversity (Pestalozza 2014a; Dombert 2012; Stiens 1997). Table 1 confirms these assumptions. It brings to the fore that all East German Land constitutions address similar issues and embrace similar principles. 
Table 1: East German constitutions: structure (number of articles, as of 12/2015)

\begin{tabular}{|c|c|c|c|c|c|c|}
\hline & a) $\mathrm{Bbg}$ & a) MW & a) $\mathrm{SA}$ & a) SAA & a) $\mathrm{TH}$ & All \\
\hline & abs. & abs. & abs. & abs. & abs. & Mean \\
\hline Principle of the Polity & 56 & 22 & 51 & 41 & 48 & 45.8 \\
\hline - Preamble & 1 & 1 & 1 & 1 & 1 & 0.9 \\
\hline - Foundation of State & 4 & 4 & 13 & 2 & 4 & 5.7 \\
\hline $\begin{array}{l}\text { - Basic rights, public goals, } \\
\text { communal life }\end{array}$ & 51 & 17 & 37 & 38 & 43 & 41.8 \\
\hline State Organs & 34 & 32 & 31 & 33 & 31 & 34.1 \\
\hline - Parliament & 20 & 21 & 20 & 23 & 22 & 22.1 \\
\hline - Government & 14 & 11 & 11 & 10 & 9 & 12.0 \\
\hline State Functions & 25 & 26 & 31 & 26 & 25 & 29.6 \\
\hline - Legislation & 7 & 6 & 7 & 6 & 5 & 7.6 \\
\hline - Executive incl. local government & 5 & 7 & 11 & 6 & 8 & 8.0 \\
\hline - Financial system & 7 & 8 & 8 & 8 & 6 & 6.9 \\
\hline - Judiciary & 6 & 5 & 5 & 6 & 6 & 7.1 \\
\hline Final clauses & 4 & 4 & 10 & 2 & 3 & 6.6 \\
\hline All & 119 & 84 & 123 & 102 & 107 & 116.1 \\
\hline
\end{tabular}

a) $\mathrm{Bbg}=$ Brandenburg; $\mathrm{MW}=$ Mecklenburg-West Pomerania; SA = Saxony; SAA = Saxony-Anhalt; $\mathrm{TH}=$ Thuringia.

Sources: My compilation based on: Pestalozza 2014b; Flick 2008b: 225.

Based on this understanding, sub-national constitutions should be rather homogeneous. Furthermore, sub-national constitutional politics should be of little 
relevance in the Länder and be shaped by intertwined decision-making. However, a closer analysis of the content of the East German constitutions and of constitutional politics in the five new Länder questions these assumptions and leads to a more differentiated picture. Three findings are crucial:

Firstly, the 'shadow hypothesis' indicates that all East German Land constitutions comply with the principles of the homogeneity clause. As a matter of fact, structure and basic principles of the constitutions of the five new Länder are very similar (table 1). They all include chapters on basic rights, state organs and state functions (Flick 2008a; Lorenz 2013). All East German Land constitutions establish a parliamentary system which is complemented by elements of direct democracy, the latter playing only a minor role so far, though (Flick 2008b: 170-85; Reutter 2008: 193-204; Eder/Magin 2008). The final chapters of the constitutions include provisions on varying topics. ${ }^{\text {III }}$ In summary it can be stated that East German constitutions comply perfectly well with the homogeneity clause. Basic principles and structures of the constitutions match the stipulations of Art. 28 par 1 of the Basic Law. Insofar the 'shadow hypothesis' can be corroborated. Yet, a closer look brings some striking differences between the constitutions and constitutional politics of the Länder to the fore. 
Table 2: East German constitutional politics compared

\begin{tabular}{|c|c|c|c|c|c|}
\hline & Brandenburg & $\begin{array}{l}\text { Mecklenburg- } \\
\text { West Pomerania }\end{array}$ & Saxony & $\begin{array}{l}\text { Saxony- } \\
\text { Anhalt }\end{array}$ & Thuringia \\
\hline Date of effect & 20.08 .1992 & 23.05 .1993 & 27.05 .1992 & 16.06.1992 & 25.10 .1993 \\
\hline Referendum & Yes & Yes & No & No & Yes \\
\hline Number of articles $(1992 / 3)$ & 118 & 81 & 123 & 102 & 107 \\
\hline $\begin{array}{l}\text { - Principles of the polity } \\
\text { (incl. basic rights) }\end{array}$ & 55 & 20 & 51 & 41 & 48 \\
\hline - State organisation & 34 & 32 & 31 & 33 & 31 \\
\hline - State functions & 25 & 26 & 31 & 26 & 25 \\
\hline - Others & 4 & 3 & 10 & 2 & 3 \\
\hline Number of articles $(09 / 2014)$ & 119 & 84 & 124 & 102 & 108 \\
\hline Number of words $(09 / 2014)$ & 8,706 & 6,528 & 8,678 & 7,724 & 7,443 \\
\hline $\begin{array}{l}\text { Number of proposed } \\
\text { amendments (until 09/2014) }\end{array}$ & 21 & 11 & 30 & 5 & 33 \\
\hline Amendments passed & 8 & 4 & 1 & 1 & 4 \\
\hline Amendment per year & 0.36 & 0.19 & 0.04 & 0.04 & 0.19 \\
\hline
\end{tabular}

Source: My compilation; websites of Land parliaments.

Table 2 provides some important information on the differences between the constitutions and constitutional politics in the five new Länder which, once again, enacted their constitutions at a similar time (1992/93) and under very similar circumstances. Yet, already the length of constitutions varies significantly. It ranged between 84 (MecklenburgWest Pomerania) and 124 articles (Saxony) and between 6,528 (Mecklenburg-West Pomerania) and 8,706 words (Brandenburg). ${ }^{\text {IV }}$ In addition, Arthur B. Gunlicks has pointed out, that East German constitutions have special signatures due to their provisions on 'modern' social rights and state goals, i.e. in those parts that might be instrumental in 
fostering regional identity (Gunlicks 2003: 154-157; Pestalozza 2014a: XXIX f.). But these signatures vary, as well. The constitutions of Brandenburg, Saxony, Saxony-Anhalt and Thuringia include more than twice as many articles dealing with the polity in principle than Mecklenburg-West Pomerania. Insofar the East German Land constitutions can hardly be regarded as uniform or homogeneous. They are rather manifestations of territorially defined values, interests and 'identities' (Dombert 2012; Jesse/Schubert/Thieme 2014: 5355; Lorenz 2013). Hans Vorländer even believes in an 'East German Constitutionalism'. He sees the eastern German Land constitutions as complimentary to the Basic Law and ascribes them the capacity to develop regional identities and integrate the people into the political and social order (Vorländer 2011; Lorenz 2011). Overall we might deduce from these features that East German Land constitutions have to comply with principles of the Basic Law and to reflect regional needs and interests. Only if they meet both requirements they might contribute to integrating the people into the political order and to fitting the subnational constitution into German cooperative federalism. Thus, sub-national constitutions have to embrace the same principles as the national Basic Law and they have to be autonomous decisions made by the Länder. 
Table 3: Adopted amendments to East German constitutions (as of 31 Dec. 2015)

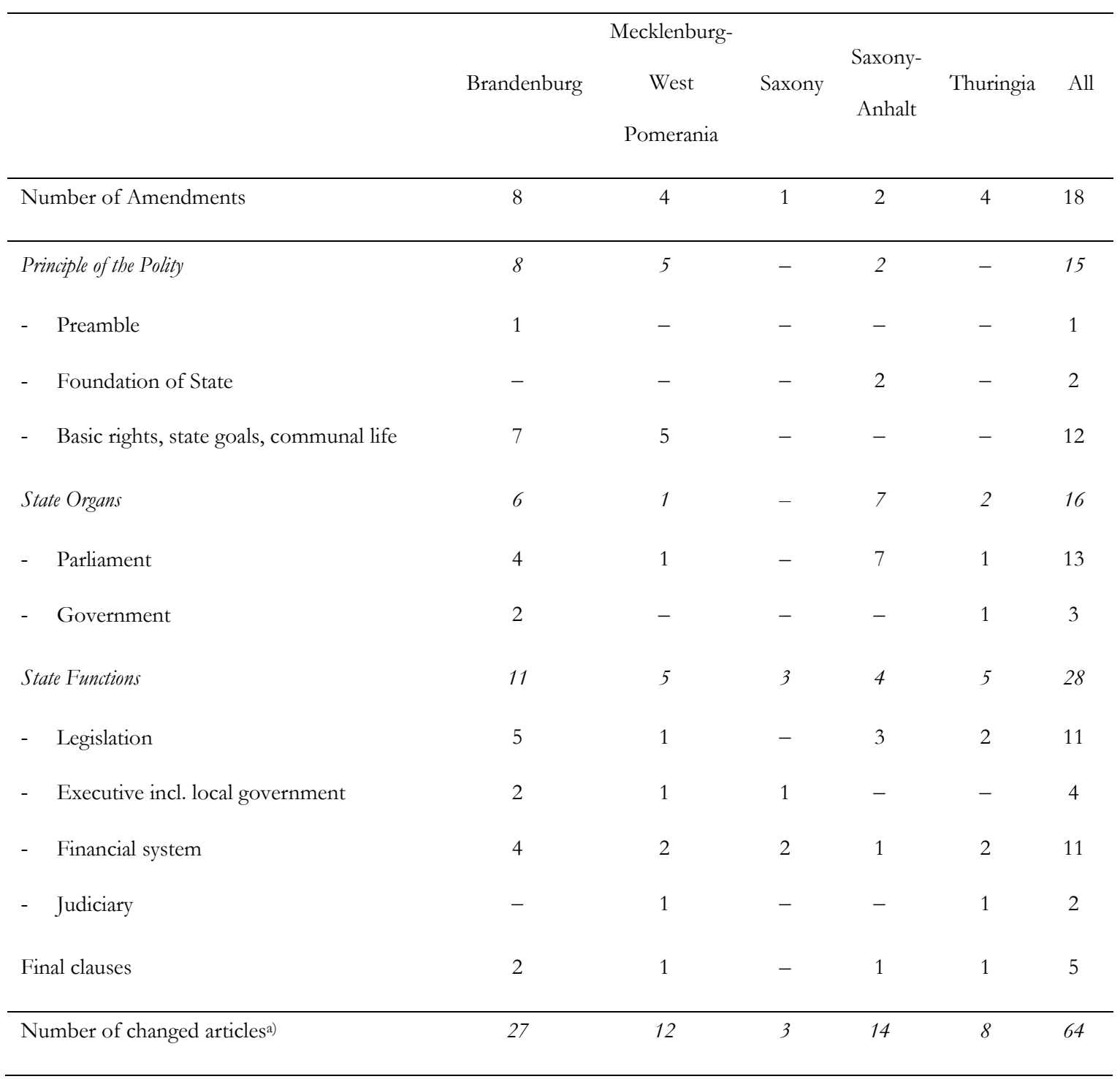

a) Some articles have been altered several times.

Source: My compilation; websites of the Land parliaments.

Finally, in the Länder constitutional politics seem to be far more important than many take for granted. Tables 3 and 4 show that this policy sector is relevant and important in the Länder. At least parties address constitutional issues regularly and frequently. For example, between 1992 and 2014 the parliaments of the five new Länder had to deal with 100 proposed constitutional amendments and adopted 18 of these proposals. This means that on average each elected parliament had to deal with a proposal to amend a constitution almost once a year. ${ }^{\mathrm{V}}$ In addition, in more than every second term an East 
German Land parliament adopted a constitutional amendment. Furthermore, 64 articles in these constitutions were changed (table 3). Or: some 10 percent of all articles of the five East German constitutions were affected by amendments in one way or another. Even though these findings do not tell us anything about the content of the amendments they still prove constitutional politics to be an important topic for parties in the Länder. Parties and parliaments deal with constitutional issues on a regular and permanent basis at the subnational level.

In addition, after 1992/3 constitutional politics took on different shapes in the East German Länder. Two dimensions are important in this respect: the number of adopted amendments and the number of all bills introduced into the five Land parliaments. As shown in table 3, between 1992 and the end of the year 2015 the number of adopted amendments varied between eight (Brandenburg) and one (Saxony). Both MecklenburgWest Pomerania and Thuringia changed their constitutions four times since these had come into effect. The eighteen amendments adopted in the five new Länder since 1992/3 changed or added sixty-four articles. Once again, there are great variations among the Länder: In Brandenburg twenty-seven articles were changed, in Saxony only three. It bears noting, though, that the passed amendments address different issues. While Saxony just added a debt brake to its constitution, Brandenburg changed its constitutional preamble and some state goals (including a clause on anti-racism, which has also been added to the constitution of Mecklenburg-West Pomerania) and adjusted also regulations on state organs and state functions. 
Table 4: Proposed amendments to East German parliaments: number of articles addressed (as of 31 Dec. 2014)

\begin{tabular}{|c|c|c|c|c|c|c|}
\hline & & Mecklenburg- & & & & \\
\hline & Brandenburg & $\begin{array}{c}\text { West } \\
\text { Pomerania }\end{array}$ & Saxony & Anhalt & Thuringia & All \\
\hline Principle of the Polity & 14 & 9 & 39 & 2 & 15 & 79 \\
\hline - Preamble & 1 & 0 & 0 & 0 & 0 & 1 \\
\hline - Foundation of State & 1 & 0 & 23 & 0 & 1 & 25 \\
\hline $\begin{array}{l}\text { - Basic rights, public goals, } \\
\text { communal life }\end{array}$ & 12 & 9 & 16 & 2 & 14 & 53 \\
\hline State Organs & 9 & 8 & 8 & 4 & 24 & 53 \\
\hline - Parliament & 5 & 5 & 4 & 4 & 19 & 37 \\
\hline - Government & 4 & 3 & 4 & 0 & 5 & 16 \\
\hline State Functions & 25 & 8 & 14 & 4 & 30 & 81 \\
\hline - Legislation & 14 & 4 & 5 & 2 & 6 & 31 \\
\hline $\begin{array}{l}\text { - Executive incl. local } \\
\text { government }\end{array}$ & 4 & 2 & 3 & 0 & 5 & 14 \\
\hline - Financial system & 3 & 2 & 4 & 1 & 12 & 22 \\
\hline - Judiciary & 4 & 0 & 2 & 1 & 7 & 14 \\
\hline Final clauses & 3 & 1 & 10 & 0 & 10 & 24 \\
\hline All & 51 & 26 & 71 & 10 & 79 & 237 \\
\hline $\begin{array}{l}\text { Number of proposed amendments } \\
\text { (until } 31 \text { Dec. 2014) }\end{array}$ & 21 & 11 & 30 & 5 & 33 & 100 \\
\hline
\end{tabular}

Source: My compilation based on the data retrieved from the websites of the Land parliaments.

There are similar patterns with regard to the number of bills submitted to the East German parliaments as shown in table 4. While the Landtage of Brandenburg, Saxony and Thuringia, had to deal with twenty-one, thirty and thirty-three respective bills since 1992/3, the parliament of Mecklenburg-West Pomerania discussed eleven bills and Saxony-Anhalt 
only five (tables 2 and 4). The number of articles to be changed by these bills varies significantly, as well (table 4). While in Saxony-Anhalt the parliamentary parties wanted to have ten articles changed, in Thuringia and Saxony seventy-nine respectively seventy-one articles were to be altered. In addition, while in Saxony the bills mostly addressed issues concerning principles of the polity, bills in Brandenburg and Thuringia focused on state functions. These differences were mostly caused by the Left Party (Die Linke, the former PDS). All in all, the Left Party submitted fifty-one bills into the East German parliaments, yet endorsed only five in Brandenburg, four in Mecklenburg-West Pomerania and two in Saxony-Anhalt. In contrast, I counted twenty-two attempts of this party in Thuringia and eighteen in Saxony. In summary, I can say that as far as the number of bills is concerned we find significant differences: between the Länder as well as between the parties. Even the same party pursued specific goals in different Länder. At least, the Left Party seemingly possessed neither a common strategy for all Länder, nor did the party coordinate their politics in this sector across the Länder. ${ }^{I I}$ The same seems true for the other parties as well. Mostly, parties supported different strategies and took a different stance on the same issue in different Länder. For example, the CDU endorsed to have a debt brake in the constitution in Brandenburg, Mecklenburg-West Pomerania and in Saxony but opposed similar proposals in Saxony-Anhalt and in Thuringia. The SPD embraced the idea of having a debt brake in the constitution in Mecklenburg-West Pomerania and in Saxony, but rejected it in the other three Länder. At the same time the Left Party opposed and the FDP endorsed such a policy in all Länder. Overall, these examples prove once again, that constitutional politics are shaped by regional interests and constellations.

As an intermediate result we can, thus, note: Firstly and not surprisingly at all: with regard to East German constitutions the most crucial point is not that they share the same principles but that they differ in important respects (Lorenz 2013). The Länder do not only enforce federal constitution stipulations but they autonomously invoke the prerogative to adopt and change their constitutions. Only under this premise can they contribute to what Vorländer has coined 'East German Constitutionalism'. Secondly, due to the separation of tasks in this policy field there is no starting point for intertwined policy-making or intergovernmental coordination. On the contrary, it would jeopardise the very essence of constitutional politics if there were a network of institutions trying to coordinate the constitutional politics of the Länder. Thirdly, constitutional politics in the Länder are 
important, permanent and salient. Or: sub-national constitutional politics matter for parties in the Länder.

Overall, we can conclude that the federal system works in a specific way with regard to sub-national constitutional politics. In this policy-sector German federalism seems dual rather than cooperative in character and neither based on cooperation nor on intertwined policy-making. This provides the institutional premise for heterogeneous policies and independent politics in the Länder and in this domain. In this respect the functioning principles of the Grand Coalition state can, hence, hardly impact on sub-national constitutional politics. In short: With regard to constitutional politics, the functioning principles of the Grand Coalition State did not effectively operate in the five new Länder. They did not shape policy-making in this area. However, there is still the second argument to be tackled with, and that is that two-thirds majorities strengthen the Grand Coalition state.

\section{Constitutional politics, the Grand Coalition state and the parliamentary form of government}

As pointed out, many assume constitutional politics to be different from 'normal' lawmaking. Obviously, this is due to the fact that in this policy sector ruling parties and parties in opposition have to find a consensus to muster the supermajority required for an amendment. ${ }^{\mathrm{VII}}$ In other words the parliamentary form of government is supposed to be suspended and replaced by policy-making based on consensus and compromise. My analysis will partly confirm this view, but I will also challenge the assumption that constitutional politics can only be understood as a manifestation of the German Grand Coalition state or consensus democracy for two reasons. On the one hand consensus democracy focuses on adopted amendments, i.e., on that 'face of power' that led to formal change. ${ }^{\text {VIII }}$ However, I find such a perspective too narrow and biased to fully capture subnational constitutional politics. I, therefore, also include bills rejected by parliaments. On the other hand, I will argue that constitutional politics in the new Länder partly comply with the logic of the parliamentary form of government and majoritarian democracy.

In order to compare normal law-making with law-making pertaining to constitutional change I construct two ideal types. Theoretically, in a parliamentary democracy the 
executive branch is legitimised and eventually held to account by a majority in parliament. If need be, in all East German Länder such a majority can bring down any government by a constructive vote of no-confidence. At the same time ruling parliamentary parties depend on the government. This interdependency between government and parliamentary majority also shapes law-making. Ideal-typically, 'normal' - i.e. majoritarian - law-making shows four features: It is dominated by the executive, governments and ruling parties are successful with their bills, parties in opposition are not successful and thus submit only few bills, and there are only few bills jointly introduced by parties from both sides of the aisle. These features have been corroborated in studies on the Bundestag and Land parliaments. ${ }^{\text {IX }}$ Table 5 summarises these features taking Michael Mezey's concept as a template: ${ }^{\mathrm{X}}$ As tables 5 and 6 reveal there are similarities, but also some differences between consensual and majoritarian law-making.

Table 5: Majoritarian and consensual types of law-making

\begin{tabular}{lcc}
\hline & $\begin{array}{c}\text { 'normal' law-making } \\
\text { (majoritarian) }\end{array}$ & $\begin{array}{c}\text { 'constitutional' law-making } \\
\text { (consensual) }\end{array}$ \\
\hline Majority & Simple majority & Two-thirds majority \\
Government & Active / successful & Passive / successful \\
Ruling parliamentary parties & Passive / successful & Passive / unsuccessful \\
Parties in opposition & Passive / unsuccessful & Active / unsuccessful \\
Coalition parties and parties in & Passive / successful & Passive / successful \\
opposition (cooperation) & & \\
\hline
\end{tabular}

Reutter 2015a: 220.

First of all, in constitutional law-making most bills are introduced by parliamentary parties not by governments as in majoritarian law-making (Reutter 2008: 230-248; Ismayr 2012: 219-224). Since 1992/3 East German governments have proposed just four amendments of which ${ }^{\mathrm{XI}}$ three have been passed. Only the CDU government of Thuringia 
(2004-2009) failed to have a debt brake included into the Land constitution. This governmental passiveness sets constitutional politics apart from 'normal' law-making. It fits with this finding that parliamentary parties supporting a government introduced even fewer bills than the governments. Ruling parties only submitted two bills on their own i.e. without parties in opposition supporting the initiative from the beginning. Both bills have been enacted, though. In these cases, the consensus was formed during the legislative process. ${ }^{\text {XII }}$ This finding supports the aforementioned view that constitutional politics are not based on intertwined policy-making. Perhaps even more importantly, this policy sector seems to rank rather low on the agenda of Land governments. Ruling parties and governments rarely took the initiative in the German Länder and submitted only few bills in this policy sector.

TABLE 6: INTRODUCED BILLS AND AMENDMENTS IN EAST GERMAN PARLIAMENTS (IN \%)

\begin{tabular}{|c|c|c|c|c|c|c|c|c|}
\hline & \multicolumn{3}{|c|}{ All Billsa) } & \multicolumn{5}{|c|}{ Proposed Amendments } \\
\hline & Bbg & SA & $\mathrm{TH}$ & Bbg & MW & SA & SAA & $\mathrm{TH}$ \\
\hline \multirow[t]{2}{*}{ Period } & $1990-$ & $1990-$ & $1990-$ & $1990-$ & $1990-$ & $1990-$ & $1990-$ & $1990-$ \\
\hline & 2014 & 2014 & 2014 & 2013 & 2013 & 2013 & 2013 & 2013 \\
\hline Absolute Number of bills / amendments & 1,003 & 1,027 & 1,065 & 21 & 11 & 30 & 5 & 33 \\
\hline \multicolumn{9}{|l|}{ Introduced by (in \%) } \\
\hline - Government & 70.9 & 56.8 & 60.1 & 14.3 & 0.0 & 0.0 & 0.0 & 6,1 \\
\hline - Ruling parties & 4.3 & 9.1 & 5.7 & 0.0 & 9.1 & 0.0 & 0.0 & 3,0 \\
\hline - Parties in opposition & 20.1 & 31.8 & 29.4 & 71.4 & 81.8 & 93.1 & 80.0 & 81.8 \\
\hline - Ruling parties and parties in opposition & 2.6 & 2.1 & 4.9 & 4.8 & 8.1 & 3.4 & 20.0 & 6,1 \\
\hline - Others & 3.4 & 0.2 & 0.2 & 9.5 & 0.0 & 3.4 & 0.0 & 3,0 \\
\hline - One party & 19.3 & 35.7 & b) 20.7 & 66.7 & 90.9 & 93.3 & 80.0 & 78.8 \\
\hline
\end{tabular}

Abbreviations: Bbg = Brandenburg; $\mathrm{MW}=$ Mecklenburg-West Pomerania; $\mathrm{SA}=$ Saxony, SAA = Saxony-Anhalt; $\mathrm{TH}=$ Thuringia

a) Proposed amendments included, b) based on the period 1990-2009.

Source: My compilation; websites of the Landtage, Landtag Brandenburg, Statistische Angaben zum Landtag, Drs. 1/3243, 2/6618, 3/7923, Stand: 20.06.2014; Patzelt 2012: 540. 
Secondly, constitutional politics seem to be more important for parties in opposition than for ruling parties. Parties in oppositions introduced most bills regardless of the fact that almost none of these bills were passed. Out of one hundred proposed amendments introduced until 31 December 2013 to the parliaments of the five new Länder eighty-two originated from parties in opposition. In Brandenburg two proposals from minority parties even led to amendments. ${ }^{\text {XIII }}$ Nonetheless, parties in opposition do not aim at effectively altering a constitution when they propose amendments, but pursue other goals. They try to influence the political agenda, present themselves as the better alternative to the incumbent government and might prepare a future participation in government. But that is exactly the task of any party in opposition also with regard to normal law-making. Hence, in this respect constitutional politics in the five new Länder fit perfectly well with the functional principles of the parliamentary form of government. This policy sector is, hence, an essential element of party competition in the Länder.

Finally, with regard to constitutional politics parliamentary parties rarely cooperate. This statement applies to parties in opposition as well as to ruling parties. In all five Länder only ten out of a hundred bills were introduced by more than one party. Of these ten bills parties in opposition jointly introduced two proposals, ${ }^{\mathrm{XIV}}$ ruling parties submitted two, as well $^{\mathrm{XV}}$ and six bills were introduced by parties in power and in opposition. ${ }^{\mathrm{XVI}}$ We find the same pattern in 'normal' law-making, where only few proposals were mutually submitted by more than one party in parliament. At least in Brandenburg, Saxony, and Thuringia between 80 and $90 \%$ of all bills were submitted by one party or the governments (table 6 ). As far as constitutional politics are concerned, amendments submitted jointly by parties in power and in oppositions were all enacted.

\section{Constitutional politics in the East German Länder - Some Tentative Conclusions}

Is Germany a Grand Coalition state also in the Länder? And does sub-national constitutional politics strengthen consensus democracy as they do at the national level? These were the questions I have tried to provide answers to. I should emphasise, though, that I did not strive to falsify the theory of Germany as a Grand Coalition state or a 
consensus democracy in general. I focused on the sub-national level which is not included in the concepts in question. Hence, I can hardly falsify or verify hypotheses that theories never claimed to make in the first place. Yet, by examining constitutional politics in the five new Länder I still tried to shed some light on a few blind spots these theories never took into account and thus to better understand how majoritarian and consensus democracy are linked to each other at least in the policy sector in question. One of my major conclusions is that these concepts are not at all mutually exclusive. On the contrary, as far as constitutional politics are concerned both components operate in the same policy sector. Thus the 'unique combination of majoritarian and consensus democracy' (Schmidt 2008: 87) typical for the German Grand Coalition state shaped a policy sector that many take as a prime example for consensus democracy.

Furthermore, I could bring to the fore that many features usually associated with German cooperative federalism and the Grand Coalition state seemingly cannot explain politics and policies in this domain. Even though it goes without saying that German federalism and the national constitution impacted on constitutional politics in the German Länder there was no indication whatsoever on intertwined policy-making or on executive networks providing governments further leverage in this field. On the contrary, in constitutional politics I found a federal system in place in which decisions are made autonomously at the Länder level. I could find no evidence that would support the assumption that joint decision-making, cooperation among Länder executives or multi-level strategies of parties had any impact in this sector. In essence, parties made different proposals in different Länder, did not coordinate the strategies across Länder, and defined their roles in the parliaments according to regional needs. My findings rather support Arthur Benz's assumption that federalism is a dynamic and flexible system that works differently in different policy sectors (Benz 1985; Jeffer et al. 2014). In other words, we still have to find a way how to causally link the impact of a multilevel system with subnational politics in different policy areas (Reutter 2014).

Finally, if the institutional set-up for cooperation cannot be referred to in the same way as at the national level to explain consensus and compromise in the Länder, we have to look for other factors. Our analysis indicates that if we take both 'faces of power' into consideration - that is not only the adopted amendments but also those rejected by parliaments - we might find constitutional politics closer to 'normal' politics than many 
assume (Busch 2006). In spite of the supermajority required for any amendment it seems that constitutional politics are instrumental for party competition in the Länder and based on the willingness of the parties to cooperate.

\footnotetext{
* Lecturer in Politics at the University of Leipzig and at Humboldt Universtiy of Berlin. Contact email: werner.reutter@r:bu-berlin.de. The research is funded by the Deutsche Forschungsgemeinschaft (grant no. GZ: LO 1424/3-1; AOBJ: 604048).

II use the terms Grand Coalition State and consensus democracy interchangeably.

II If not otherwise indicated I retrieved the information on introduced bills and adopted amendments from the websites of the Land parliaments. Even though the access to these websites differ in detail, I proceeded in principle as follows: I searched the respective websites by looking for 'bills' (Dokumentyp: Gesetzentwurf) on the subject 'Landesverfassung'. Then I checked all entries for relevance and for the data we needed.

III In its final part the constitution of Brandenburg addresses issues such as: the constitutional court (Art. 114), how a new constitution is to be adopted (Art. 115), a possible amalgamation of the Land with another Land, and when the constitution comes into effect (Art. 117). The respective articles in the constitution of Mecklenburg-West Pomerania (Art. 78-80) rule: that each pupil will get a copy of the constitution on the first day at school, that texts in official documents will include both the male and the female form, that from 2012 onwards the budget has to be set up in such a way that in 2020 the debt brake will come into effect, and the day when the constitution comes into effect.

IV I compare constitutional policies by using formal characteristics like the number of articles or bills. Comparing constitutions in such a way runs into a number of problems, though. For example, the content of provisions can vary even if these have the same number of articles or words. Furthermore, stipulations addressing the same issue might figure in different chapters of a constitution. For instance, in the constitution of Saxony the parts on the 'Foundation of the State' (Grundlagen des Staates) include provisions on social rights, state goals (Staatsziele), or on communal life (Gemeinschaftsleben). In contrast, Brandenburg's constitution includes a separate chapter on these issues. Or: Chapters on the judiciary not only include provisions on this state function but also on state organs. In order to avoid such problems of assignment we subsumed all articles of a constitution under four headings (table 1).

v Between 1992 and 2014 each elected parliament of the five new Länder existed some 22 years, i.e. in sum 110 years. In this period 100 amendments had been submitted to the five parliaments, thus on average 0.9 bills had to be dealt with per year. Furthermore, until the end of 201428 parliamentary elections had been taken place, which means that on average each elected parliament passed 0.6 constitutional amendments.

VI We find similar patterns with regard to the question of whether the debt brake should be included in Land constitutions. In some Länder the CDU, SPD and the Green Party supported such a policy while they opposed it in other Länder, see: Sturm 2011.

VII So far four coalitions could rely on a two-thirds majority in East German parliaments: there were three coalitions including the SPD and the CDU in Brandenburg (1999-2004), Mecklenburg-West Pomerania (1994-1998) and Thuringia (1994-1999); in addition one coalition composed of SPD and PDS (1994-1998) had a majority in parliament of 66.2 percent.

VIII I gleaned this concept from Bachrach/Baratz 1962.

IX As far as law-making in general is concerned we have respective data for only three East German Länder. For overviews on Land parliaments and law-making see Reutter 2013: 63-71; Ismayr 2008: 383-429; Reutter 2008: 230-256.

x It should be noted, though, that Michael Mezey asks a different question and compares legislatures, hence, not different types of legislative decision-making; Mezey 1979.

XI Landtag Thüringen, Drs. 3/2237 (28.02.2002) and Drs. 4/4969 (12.03.2009); Landtag Brandenburg, Drs. 2/678 (27.04.1995), and Drs. 3/7444 (28.04.2004).

XII These amendments had the debt brake included in the constitution of Mecklenburg-West Pomerania and reorganised the remuneration for parliamentarians in Thuringia; Landtag Mecklenburg-Vorpommern, Drs. 5/4192 (2.3.2011); Landtag Thüringen, Drs. 2/2381 (6.11.1997).

XIII Landtag Brandenburg, Drs. 2/3657 (16.01.1997), 2/3658 (16.011997), and 5/1880 (25.08.2010).

XIv Landtag Brandenburg Drs. 5/2045 (23.09.2010), Landtag Thüringen Drs. 3/1911 (24.10.2001).

xv Landtag Thüringen Drs. 2381 (6.11.1997), Landtag Mecklenburg-Vorpommern Drs. 5/4192 (2.3.2011).
} 
XVI Landtag Brandenburg, Drs. 5/7321 (21.05.2013); Landtag Mecklenburg-Westpomerania, Drs. 4/2118 (neu) (6.3.2006), Landtag Sachsen, Drs. 5/11838 (30.04.2013), Landtag Saxony-Anhalt, Drs. 4/1634 (16.06.2004), Landtag Thuringia, Drs. $3 / 3651$ (9.10.2003), Drs. 4/211 (30.09.2004).

\section{References}

- Bachrach Peter and Baratz Morton S., 1962, 'Two Faces of Power', American Political Science Review, LVI(4): 947-952.

- $\quad$ Benz Arthur, 1985, Föderalismus als dynamisches System, Westdeutscher Verlag, Opladen

- Busch Andreas, 2006, 'Verfassungspolitik: Stabilität und permanentes Austarieren', in Schmidt Manfred G. and Zohlnhöfer Reimut (eds), Regieren in der Bundesrepublik Deutschland, VS Verlag für Sozialwissenschaften, Wiesbaden, 33-56.

- Dombert Matthias, 2012, ‘27 Landesverfassungen und Landesverfassungsgerichte in ihrer Bedeutung für den Föderalismus', in Härtel Ines (ed), Handbuch Föderalismus - Föderalismus als demokratische Rechtsordnung und Rechtskultur in Deutschland Europa und der Welt, Springer, Berlin, 19-38.

- $\quad$ Eder Christina and Magin Raphael, 2008, 'Direkte Demokratie', in Freitag Markus and Vatter Adrian (eds), Die Demokratien der deutschen Bundesländer, Barbara Budrich, Leverkusen/ Opladen, 257-308.

- $\quad$ Flick Martina, 2008a, 'Landesverfassungen und ihre Veränderbarkeit', in Freitag Markus and Vatter Adrian (eds), Die Demokratien der deutschen Bundesländer. Politische Institutionen im Vergleich, Verlag Barbara Budrich, Opladen, 221-236.

- $\quad$ Flick Martina, 2008b, 'Parlamente und ihre Beziehungen zu den Regierungen', in Freitag Markus and Vatter Adrian (eds), Die Demokratien der deutschen Bundesländer. Politische Institutionen im Vergleich, Verlag Barbara Budrich, Opladen, 161-194.

- Gunlicks Arthur B., 1996, 'The new constitutions of east Germany’, German Politics, V(2): 262-275.

- Gunlicks Arthur B., 2003, The Länder and German Federalism, Manchester University Press, Manchester.

- Gunlicks Arthur B., 2012, 'Legislative Competences, Budgetary Constraints, and the Reform of Federalism in Germany from the Top Down and the Bottom Up', in Burgess Michael and Tarr G. Alan (eds), Constitutional Dynamics in Federal Systems, McGill Queen’s University Press, Montreal etc., 61-87.

- Hölscheidt Sven, 1995, 'Die Praxis der Verfassungsverabschiedung und der Verfassungsänderung in der Bundesrepublik', Zeitschrift für Parlamentsfragen, XXVI(1): 58-84.

- Ismayr Wolfgang, 2008, 'Gesetzgebung im politischen System Deutschlands', in Ismayr Wolfgang (ed), Gesetəgebung in Westeuropa. EU-Staaten und Europäische Union, VS Verlag für Sozialwissenschaften, Wiesbaden, 383-429

- $\quad$ Ismayr Wolfgang, 2012, Der Deutsche Bundestag, $3^{\text {rd }}$ edition, Springer VS, Wiesbaden.

- Jeffery Charlie, Pamphilis Niccole M., Rowe Carolyn and Turner Ed, 2014, 'Regional policy variation in Germany: the diversity of living conditions in a "unitary federal state", Journal of European Public Policy, XXI(9): 1350-1366.

- Jesse Eckart, Schubert Thomas and Thieme Tom, 2014, Politik in Sachsen, Springer VS, Wiesbaden.

- $\quad$ Katzenstein Peter J., 1987, Policy and Politics in West Germany. The Growth of a Semisovereign State, Temple University Press, Philadelphia, PA.

- $\quad$ Kropp Sabine, 2010, Kooperativer Föderalismus und Politikverflechtung VS Verlag für Sozialwissenschaften, Wiesbaden.

- Landtag Brandenburg, ELVIS Parlamentsdokumentation. https://www.parlamentsdokumentation.brandenburg.de/

- Landtag Mecklenburg West-Pomerania. Parlamentsdokumentation. http://www.dokumentation.landtag-mv.de/Parldok/

- Landtag Saxony, Parlamentsdokumente (EDAS). http://edas.landtag.sachsen.de/

- Landtag Saxony-Anhalt. Parlamentsdokumentation PADOKA. http://padoka.landtag.sachsenanhalt.de/starweb/PADOKA/index.htm

- Landtag Thuringia. Parlamentsdokumentation. http://www.parldok.thueringen.de/parldok 
- Laufer Heinz and Münch Ursula, 2010, Das föderale System der Bundesrepublik Deutschland, $8^{\text {th }}$ edition, Bayerische Landeszentrale für politische Bildungsarbeit, Munich.

- $\quad$ Lijphart Arend, 1999, Patterns of Democracy. Government Forms and Performance in Thirty-Six Countries, Yale University Press, New Haven.

- Lorenz Astrid, 2011, 'Die ostdeutschen Landesverfassungen als dynamische Integrationsstifter', in Lorenz Astrid (ed), Ostdeutschland und die Sozialwissenschaften. Bilanz und Perspektiven 20 Jahre nach der Wiedervereinigung, Verlag Barbara Budrich, Leverkusen, 75-98.

- Lorenz Astrid, 2013, Demokratisierung in Ostdeutschland. Verfassungspolitische Weichenstellungen in den neuen Ländern und Berlin, Springer VS, Wiesbaden.

- Lorenz Astrid and Reutter Werner, 2012, 'Subconstitutionalism in a Multilayered System. A Comparative Analysis of Constitutional Politics in the German Länder', Perspectives on Federalism, IV(2): 141170, available at http://www.on-federalism.eu/attachments/141_download.pdf (accessed 3 January 2014).

- Mezey Michael, 1979, Comparative Legislatures: Duke University Press, Durham, NC.

- Möstl Markus, 2005, 'Landesverfassungsrecht - zum Schattendasein verurteilt? Eine Positionsbestimmung im bundesstaatlichen und supranationalen Verfassungsverbund', Archiv des öffentlichen Rechts, CXXX: 350-391.

- $\quad$ Patzelt Werner J., 2014, 'Landesparlamentarismus in Deutschland: Sachsen', in Mielke Siegfried and Reutter Werner (eds), Landesparlamentarismus. Geschichte - Struktur - Funktionen. Mielke, 2 ${ }^{\text {nd }}$ edition, VS Verlag, Wiesbaden, 509-548.

- Pestalozza Christian, 2014a, 'Einführung', in Pestalozza Christian (ed), Verfassungen der deutschen Bundesländer mit dem Grundgesetz. Textausgabe mit einer Einfübrung von Christian Pestalozza, $10^{\text {th }}$ edition, C.H. Beck, Munich, XVII-CXLVII.

- $\quad$ Pestalozza Christian (ed), 2014b, 'Verfassungen der deutschen Bundesländer mit dem Grundgesetz. Textausgabe mit einer Einführung von Christian Pestalozza, 10 th edition, C.H. Beck, Munich.

- Reutter Werner, 2006, 'The Transfer of Power Hypothesis and the German Länder. In Need of Modification', Publius. The Journal of Federalism, XXXVI(2): 277-301.

- Reutter Werner, 2008, Föderalismus, Parlamentarismus und Demokratie. Landesparlamente im Bundesstaat, Verlag Barbara Budrich (utb), Opladen.

- $\quad$ Reutter Werner, 2010, “'Grand Coalition State”, Große Koalition und Föderalismusreform’, in Bukow Sebastian and Seemann Wenke (eds), Die Große Koalition, VS Verlag für Sozialwissenschaften, Wiesbaden, 85101.

- $\quad$ Reutter Werner, 2013, Die Zukunft des Landesparlamentarismus. Der Landtag Nordrhein-Westfalen im Bundesländervergleich, Springer VS, Wiesbaden.

- Reutter Werner, 2014a, 'Sächsische Verfassungspolitik', in Jahrbuch des Föderalismus 2014, Nomos, Baden-Baden, 255-268.

- $\quad$ Reutter Werner, 2014b, 'Multilevel Systems and Sub-National Constitutional Politics in Germany: a Qualitative Comparative Analysis', Perspectives on Federalism, VI(2), 215-243, available at: http://www.onfederalism.eu/attachments/186 download.pdf (accessed: 1 October 2016).

- Reutter Werner, 2015a, 'Bayerische Verfassungspolitik', in Jahrbuch des Föderalismus 2015, Nomos, Baden-Baden, 215-227.

- Reutter Werner, 2015b, 'Verfassungsgesetzgebung in Brandenburg', Zeitschrift für Parlamentsfragen, XLVI(1): 116-135.

- $\quad$ Reutter Werner, 2016, Verfassungspolitik in Baden-Württemberg: Ergebnis konsensdemokratischer Zwänge oder "normale Politik mit anderen Mitteln"?', Zeitschrift für Politikwissenschaft, XXVI(2): 131-151. DOI: 10.1007/s41358-016-0030-7.

- Reutter Werner, 2017, 'Landesverfassungsgerichte in der Bundesrepublik Deutschland - eine politikwissenschaftliche Bestandsaufnahme', in Reutter Werner (ed), Landesverfassungsgerichte in der Bundesrepublik Deutschland, VS Springer, Wiesbaden, 21-48 (in print).

- $\quad$ Reutter Werner and Lorenz Astrid, 2015, 'Explaining the Frequency of Constitutional Change in the German Länder: Institutional and Party Factors', Publius: The Journal of Federalism, XLVI(1): 103-127. Doi: 10.1093/publius/pjv041.

- $\quad$ Schmidt Manfred G., 1987, 'West Germany: The Politics of the Middle Way', Journal of Public Policy, VII: 139-77. 
- Schmidt Manfred G., 1996, 'When parties matter: A review of possibilities and limits of partisan influence on public policy', European Journal of Political Research, XXX(2): 155-183.

- Schmidt Manfred G., 2008, 'Germany. The Grand Coalition State', in Colomer Josep M. (ed), Comparative European Politics, $3^{\text {rd }}$ edition, Routledge, London etc., 58-92.

- Stiens Andrea, 1997, Chancen und Grenzen der Landesverfassungen im deutschen Bundesstaat der Gegenwart, Duncker \& Humblot, Berlin.

- Sturm Roland, 2011, 'Verfassungsrechtliche Schuldenbremsen im Föderalismus', Zeitschrift für Parlamentsfragen, XLVI(3): 648-662.

- Vorländer Hans, 2011, 'Verfassungstheorie und demokratischer Transitionsprozess. Der (ost-) deutsche Konstitutionalismus', in Lorenz Astrid (ed), Ostdeutschland und die Sozialwissenschaften. Bilanz und Perspektiven 20 Jahre nach der Wiedervereinigung, Verlag Barbara Budrich, Leverkusen, 245-260. 